Fikrah: Jurnal Ilmu Aqidah dan Studi Keagamaan

issn 2354-6174 eissn 2476-9649

Tersedia online di: journal.iainkudus.ac.id/index.php/fikrah

Volume 8 Nomor $12020,(1-24)$

DOI: $10.21043 /$ fikrah.v8i1.7063

\title{
Shaer Yang di-Pertuan: Tinjuan Historis Relasi Umara dan Ulama di Brunei Darussalam
}

\author{
Izzah Naqibah binti Kamis \\ Universiti Islam Sultan Sharif Ali \\ Naqibah.kamis@gmail.com
}

\author{
Muhammed Sahrin bin Haji Masri \\ Universiti Islam Sultan Sharif Ali \\ sahrin.masri@unissa.edu.bn
}

\begin{abstract}
Abstrak
Umara dan ulama adalah dua golongan yang sangat berpengaruh dengan tampilan hubungan dasar dalam perkembangan Negara Brunei Darussalam. Pada dasarnya Ulama memiliki sifat sebagai pewaris para nabi, mereka beperanan sebagai mursyid dalam masyarakat Melayu. Fenomena ini telah dijelaskan dengan keutamaan nama-nama mereka dalam beberapa bahan nadir seperti manuskrip, batu dan tersilah, hikayat dan sebagainya. Namun para ulama jarang menonjolkannya dalam paparan dengan pendekatan berbentuk syair. Karya "Shear Yang Di-Pertuan" adalah salah satu syair yang pernah ditulis dan dapat dianggap sebagai bagian terpenting dari Brunei Darussalam. Syair ini ditulis oleh Pehin Siraja Khatib Awang Abdul Razak bin Hasanuddin, seorang Ulama Brunei yang terkenal sekitar akhir abad ke 19 dan awal abad ke 20. Terdapat banyak peristiwa penting pada masa pemerintahan Sultan Muhammad Jamalul Alam II (Sultan Brunei ke 26) yang dipaparkan dalam syair ini. Atas dasar ini, kajian ini akan menerangkan beberapa komponen penting dalam "Syaer Yang Di-Pertuan" dan mengenai bagaimana hubungan umaraulama berjalan dalam masa yang sama akan mengetengahkan beberapa orang ulama yang terlibat secara langsung kerana mereka ini cukup berpengaruh sebagai penyambung perjuangan menyebarkan Islam di NBD dan berperanan dalam perkembangan kenegaraan dan pentadbiran di Brunei Darussalam.
\end{abstract}

Kata Kunci: ulama, umara, shaer yang di-pertuan, sejarah 


\begin{abstract}
Umara and Ulama are two groups who are very influential and has very basic relationships on the State of Brunei Darussalam's growth. Basically, Ulama are known as someone who inherits Anbiya's character, they play a role as murshid in Malay society. This phenomenon has been explained by the importance of their names in some rare materials such as manuscripts, stones and artifacts, hikayat and so on. But The Ulama rarely present it as a poetic/syair approach. The work of "Shaer Yang Di-Pertuan" is one of the poems/syair ever written and can be considered as the most important part of Brunei Darussalam. This poems/syair was written by Pehin Royal Khatib Awang Abdul Razak bin Hasanuddin, a famous Ulama from Brunei, around the late 19th and early 20th centuries. This poems/syair was produced by Pehin Siraja Khatib Awang Abdul Razak bin Hasanuddin, a famous Brunei Ulama around the end of the 19th century and the beginning of the 2oth century. There are many important events during the reign of Sultan Muhammad Jamalul Alam II (26th Sultan of Brunei) featured in this poems/syair. Based on it background, this study will explain some of the key components of the "Syaer Yang Di-Pertuan". In addition, there are some explanations of how the umara-ulama relationship works at the same time will highlight some of the ulama who involved directly. This is because they have a significant influence on the struggle that took place at that time, especially in spreading Islam in the NBD and its role in the development of nationalism and governance in Brunei Darussalam.
\end{abstract}

Keywords: history, ulama, umara, shaer yang di-pertuan,

\title{
Memahami Makna Umara dan Ulama
}

Perkataan umara adalah berasal dari Bahasa Arab berbentuk jama' taksir dari perkataan Amir. Ia berasal dari perkataan amara - ya'muru, yang bermaksud memberi arahan (pemimpin) (Awang Othman, 2002, hal. 14). Hal ini juga mengacu pada Firman Allah SWT dalam Q.S al-Taubah: 112.

"(Orang-orang yang beriman itu ialah:) orang-orang yang bertaubat yang beribadat, yang memuji Allah yang mengembara (untuk menuntut ilmu dan mengembangkan Islam) yang rukuk, yang sujud, yang menyuruh berbuat kebaikan dan yang melarang daripada kejahatan, serta yang menjaga batas-batas hukum Allah. Dan gembirakanlah orang yang beriman (yang bersifat demikian)".

Pada dasarnya, Islam mengenal beberapa term yang mempunyai kesamaan makna dengan kata umara yaitu imam, khalifah dan ulil amri. Sedangkan penggunaanya berbeda karena konteks sosial dan psikologi pengguna, seperti dalam sistem imamah yang dianut oleh kalangan Syiah yang merujuk pada sistem kepemimpinan menyeluruh yang berkaitan dengan urusan keagamaan murni sebagai pengganti Nabi. Hal ini berbeda dengan 
konteks penggunaan khilafah yang dipilih oleh rakyat ataupun Ahl al-Hill wa al-Aqd, dan ini bersifat ijtihadi (Anas, 2018).

Begitu juga penggunaan secara etimologi yang merujuk kepada umara yang mempunyai terma berbeda telah banyak disebutkan dalam al-Quran (Awang Othman, 2002, hal. 6-15) seperti dalam Q.S al Baqarah; 124 kisah Nabi Ibrahim yang dilantik menjadi imam bagi umat manusia. Pada ayat yang lain Allah menggunakna kata khalifah dan ulill amri yang menunjukkan pada sifat umara dalam al Quran, seperti Q.S Yunus 14 dan Q.S al Nisa 59. Ayat pertama menceritakan tentang Nabi Muhammad sebagai khalifah dan pengganti dari nabi yang telah wafat. Begitu juga dengan ayat lain di mana Allah berfirman tentang ketaatan masyarakat kepada penguasa atau ulil amir. Namun hal ini tidak menutup kemungkin pergeseran makna terjadi dari perkembangan masa, seperti penggunaan terma umara, raja, sultan, king, dan term yang mempunyai makna sepdana (Yaacob, 2017, hal. 5).

Tanggung jawab yang berat dan menyeluruh, sehingg orang yang mendapatkan predikat umara harus mempunyai standar yang tinggi. Dalam kontek ini, al Mawardi (2002) seorang kasarjaan muslim membahas secara khusus tentang kepatututan orang disebut sebagai umara, dan memberikan tujuh syarat yaitu: pertama, adil yaitu menempatkan perkara atau sesuai dengan keadaan dengan memperhatikan kondisi; kedua, mempunyai ilmu sehingga mampu melakukan ijtihad dalam menghadapi segala persoalan dan hukum. Sekiranya seseorang pemimpin tidak mempunyai ilmu, maka dia tidak akan dapat mengemukakan ijtihad secara tepat. (Khaldun, 2002, hal. 203).

Ketiga, sempurna pancainderanya yaitu tidak mempunyai cacat secara intelektual sehingga dalam mengambil keputusan tidak mempunyai kecenderungan; keempat, sempurna anggota tubuh badan dan tidak terhalang dari menjalankan tugasnya, yaitu tidak mempunyai cacat secara fisik karena membantuk dalam mengambul keputusan yang adil; kelima, mempertimbangkan dan mendahulukan kepentingan rakyat di atas kepentingan pribad dan golongan. Oleh sebab itu, pemimpin pada dasarnya menjadi ujung tombak dalam menghadapi problematika kenegaraan dan dituntut mampu mengendalikan persoalan yang bersifat lokal, nasional dan internasional (Khaldun, 2002, hal. 191).

Lebih lanjut al-Mawardi menerangkan syarat keenam berani dan mampu menentang musuh, yaitu mempunyai sikap tegas dalam mencegak 
kemungkaran yang dilakukan oleh seorang atau kelompok; ketujuh, berketurunan dari Quraisy, yaitu ini diperolehi daripada ijmak para sahabat ketika Abu Bakar Radiallahu anhu di lantik sebagai seorang Khalifah. Kesepakatan ini diambil karena para Kabilah Quraisy mempunyai sikap yang tegas dan pemberani (Mawardi, 2002).

Sepadan dengan term umara, ulama juga mempunyai dasar term yang terbentuk dari Bahasa Arab yang berbentuk plural dari jama' taktsir yaitu 'alima- ya'lamu - 'ilman, sebagaimana yang terdapat dalam Q.S al Fahir; 28.

"Dan demikian (pula) di antara manusia, binatang-binatang melata, dan binatang-binatang ternak ada yang bermacam-macam warnanya (dan jenisnya). Sesungguhnya yang takut kepada Allah di antara hambahambaNya, hanyalah ulama. Sesungguhnya Allah Maha Perkasa lagi Maha Pengampun."

Ayat tersebut menandakan bagaimana sikap ulama yang mempunyai keistimewaan dan berbeda dengan ciptaan Allah yang lain. Dengan demikian, ulama mempunyai makna orang yang memiliki ilmu yang mandalam, luas dan mantap. Begitu juga dengan penggunaan terma ulama disesuaikan dengan kontek sosio-psikologi masyarakat yaitu Kiyai, Tuan Guru, Baba, Teuku, Khatib, Mudim dan sebagainya.

Meskipun demikian, kita dapat melihat perbedaan definisi ulama yang dijelaskan para sarjana muslim klasik, seperti Hasan Basri (Maraghi, 2002, hal. 127) yang mengartikan ulama sebagai orang yang takut kepada Allah SWT, Mujahid yang memaknai ulama dengan orang yang hanya takut kepada Allah SWT, Ibnu Katsir (Adz-Dzahabi, 2010, hal. 164) dan Sayid Qutb memaknai ulama adalah orang yang senantiasa berpikir kritis akan kitab AlQurean (yang mendalam maknanya) sehingga mereka akan ma'rifat secara hakiki kepada Allah.

\section{Urgensi Kedekatan Umara dan Ulama}

Kedua golongan umara dan ulama adalah golongan yang dipandang tinggi oleh masyarakat dan saling memerlukan antara satu sama lain terutama dalam hal pentadbiran (penjelasan) negara yang memerlukan cetusan (putusan) idea dan ijtihad para ulama. Kedekatan dan persatuan ulama dan umara merupakan satu keniscayaan dalam kontek kehidupan sosial, karena kedua kelompok tersebut merupakan komponen penting dalam persatuan masyarakat secara umum. Menurut Kamil (1999) ulama merupakan strata sosial yang ikut berkontribusi dalam merubah tatanan sosial, sehingga 
kehadiran ulama dalam konteks pemerintahan merupakan peran penting dan strategis. Pentingnya adanya ulama sebagai media untuk menjelaskan kandungan ajaran agama dijelaskan dalam Q.S al Nahl 43:

"Oleh itu, bertanyalah kamu kepada orang berpengetahuan agama jika kamu tidak mengetahui"

Kandungan ayat tersebut memberikan pemahaman pentingnya orang yang memahami ajaran agama secara penuh sebagai rujukan bagi masyarakat untuk mencari jawaban atas solusi yang dihadipi dari problematika agama di tatanan sosial. Oleh sebab itu, ulama dalam menjelaskan al Quran mempunyai sifat hati-hati untuk menyampaikan maknanya, sehingga penjelasan atas al Quran menjadi empat sumber utama yang diyakini sebagai rujukan otoritatif seperti al Quran, al sunah, ijma' dan Qiyas (Khallaf, 1990). Ulama sebagai rujukan juga dapat membantu umara (pemerintah) untuk memberikan solusi, saran dan kritik yang dapat menyelesaikan problematikan kenegaran.

Gandingan (kedekatan) yang signifikan antara umara dan ulama akan memberikan impak (konsekuensi) dalam sesebuah negara. Dalam kontek ini, sejarah telah mencatat bagaimana indahnya persandingan ulama dan umara dalam kenegaraan, seperti kisah Nabi Muhammad yang dalam statusnya menjadi Nabi, tetapi juga bisa menjadi kepala negara dan ini terus berlanjut kepada para sahabat dan khalifah Islam pada masa awal yang menjadi umara (kepala pemerintah) dan sekaligus juga mempunyai kompetensi dan diakui sebagai ulama, sehingga dalam mencari solusi kenegaraan dapat memberikan kemaslahatan masyarakat (Qardawi, 1997). Persandingan ulama dan umara dalam melayani masyarakat dalam institusi pemerintahan yang berlandaskan akal sematar, akan terjebak pada paham materialism. Begitu juga pemerintahan yang berorientasi pada agama saja juga menyebabkan kekosongan dalam ilmu dunia dan juga tidak bagus. Oleh sebab itu, keseimbangan antara dunia dan agama harus bersinergi dalam menjalankan roda pemerintah. Dengan Bahasa sederhana bahwa kesimbangan ulama dan umara dalam menjalankan roda pemerintahan harus seimbang, ulama menjadi dasar dan pertimbagnan dalam mengambil keputusan. Begitu juga dengan umara yang menjadi eksekutor dalam putusan yang diambil untuk kemaslahatan masyarakat, sebagaiman sejarah Islam awal yang mengisahkan persandingan elok dan indah antara status sebagai ulama dan umara (Khaldun, 2002). 


\section{Relasi Umara dan Ulama dalam Tinjuan Sejarah Islam Awal}

Sejarah telah mencatat masa keemasan peradaban Islam awal yang berdiri kokoh dan menguasai bidang keilmua, hal ini berkat kerjasama antara ulama dan umara dalam mengurus negara. Kedua kelompok tersebut adalah komponen yang saling melengkapi. Hubungan dua status yang harmoni antara umara dan ulama yang menjadi satu hubungan yang signifikan dalam membina sesebuah negara yang berlandaskan syariat Islam. Kepedulian para umara akan golongan ulama menjadikan para ulama ini dipandang tinggi oleh masyarakat, begitu juga sebaliknya, kepedulian Ulama atas umara dapat menumbuhkan cinta masyarakat pada pemimpin.

Salah satu contohnya pada zaman Kerajaan Umayyah, Khalifah Abdul Malik bin Marwan dikenali sebagai seorang khalifah yang mendampingi para ulama sehingga sehingga digelar sebagai 'Hamamah al-Masjid' (Toqus, 2010, hal. 66). Beliau juga menjadikan Bahasa Arab sebagai bahasa rasmi kerajaan, lebih lagi bahasa Arab tersebut merupakan Bahasa Al-Quran (Toqus, 2010). Menurut Hayani dan Bakhtiar (2020) menjadi pelopor dalam memajukan dan mengembangkan pemerintahan Arab dengan menyebarkan syariat-syariat Islam. Namun, kendala yang dihadapi juga tidak mudah, karena harus menghadapi penguasa Hajjaj bin Yusuf. Status Khalifah Abdul Malik bin Marwan yang mempunyai dua status yaitu sebagai umara sekaligus orang yang paham agama, lebih mudah untuk mengkoordinasi keadaan secara duniawi dan akhirat. Adapun prestasi selain menjadikan menjadikan bahasa Arab menjadi bahasa resmi negara juga mengganti mata uang, pembaharuan ragam tulisan bahasa Arab, pembaharuan bidang perpajakan, pengembangan sistem pos, dan kerajinan.

Begitu juga pada zaman Khalifah Umar bin Abdul Aziz, beliau menghantar para pegawai ke wilayah-wilayah untuk menyeru rakyat supaya memeluk Agama Islam. Selain itu, beliau juga menjadi ikutan bagi rakyatnya disebabkan yang zuhud dan melaksanakan tanggungjawab dengan baik (Toqus, 2010). Kecintaan Khalifah Umar bin Abdul Aziz kepada ilmu agama sehingga ia memutuskan untuk menginisiasi pembukuan hadis Nabi Muhammad (Qudsy, 2013). Selian itu, beliau juga menjadi Khalifah yang mencatatkan sejarah beridirinya pusat studi ilmu yang disebut dengan baitul hikmah dan juga tempat koperasi umat dengan baitul malnya yang dikelola untuk kepentingan rakyatnya. Oleh sebab itu, beliau mencatatkan sejarah 
yang memperhatikan pengetahuan maupun taraf hidup masyarakat yang telah mampu menikmati hidup sejahtera itu aman dan damai (Muslim, 2019)

Pada zaman kegemilangan kerajaan Abbasiyah, percambahan ilmu semakin berkembang dan hasilnya kedua golongan ini bergiat dalam membangunkan beberapa institusi pengajian terkenal. Antaranya, Madrasah Nizamiyah, Madrasah al-Mustansiriyyah, Madrasah al-Nasiriyyah dan Madrasah al-Nuriyah yang menawarkan kurikulum yang pelbagai dan lengkap dengan fasilitinya (Mohamad Kamil Ab. Majid, 1999, hal. 88) Selain membina institusi pengajian, kedua golongan ini juga saling mendokong kearah usaha penterjemahan karya-karya Yunani, Hindi dan sebagainya ke Bahasa Arab (L. Salim, 2015, hal. 172). Perlu diketahui bahwa kemajuankemajuan dinasti Abbasiyah diperoleh seiring dengan membaiknya perekonomian yang mulai meningkat, terutama dari sektor pertanian melalui irigasi dan peningkatan hasil pertambangan seperti emas, perak, tembaga dan besi. Kemajuan dalam sektor ini diikuti dengan perbaikan-perbaikan internal yang cukup bagus baik dalam sistem administrasi dan pemerintahan yang menunjukkan kematangan dalam berpikir (Edianto, 2017). Peristiwa sejarah tersebut merupakan rentetan kemajuan Islam pada masa awal yang menggabungkan status atau adanya koordinasi antara ulama dan umara dalam melayani masyarakat pada taraf hidup dan pengetahuan yang semakin membaik.

\section{Hubungan Umara dan Ulama: Brunei Darussalam}

\section{Era Tradisi}

Hubungan umara dan ulama di Brunei Darussalam sudah terjalin lama yaitu pada awal abad ke 10 Masehi, ketika Raja Bo Ni yang bernama Xiang Da mengirimkan utusan yang bernama Shi Nu (Syeikh Noh), Pu Ya Li (Abu Ali) dan Pan Guan Ge Xin (Kadhi Kasim) untuk membawa surat dan barangbarang ufti ke China pada tahun 977 Masehi.

Sekitar abad ke-15, seorang umara merangkap seorang ulama dari Tha' if telah dilantik sebagai Sultan bagk menggantikan Sultan Ahmad. Hal ini telah disebutkan dalam Silsilah Raja-Raja Brunei:

"....Maka Sharif Ali itulah kerajaaan dinamai akan dia Paduka Seri Sultan Berkat dan ialah mengeraskan syariat Rasulullah Sallallahu Alaihi Wasallam dan berbuat masjid..." (Sweeney, 1968, hal. 11) 
Selang beberapa keturunan setelah Sultan Sharif Ali, yaitu Sultan Saiful Rijal yang merupakan salah seorang umara yang mendekati para ulama. Pada masa pemerintahannya terjdilah perselisihan dengan Francisco De Sande yang disebabkan adanya surat yang dikirimkan oleh Francisco de Sande kepada Sultan Saiful Rijal yang berisikan:

“...patik menghendaki Duli Tuanku jangan menghantar mubalighmubaligh ajaran Mahoma (Islam) ke mana-mana bahagian kepulauan ini atau kepada orang 'Tingues' (orang bukit) yang masih jahiliah itu, dan tidak juga ke kawasan pulau Duli Tuanku sendiri..." (Haji Umar, 1990, hal. 36)

Ketika Sultan Saiful Rijal membaca surat itu, baginda sangat murka mengenai hasrat Francisco De Sande yang menolak para mubalig (utusan keagamaan) Muslim untuk masyarakat perbukitan dan satu pula karena dianggap belum memeluk agama Islam. Adapun sebagai konsekuensi dari lanjutan dari peristiwa tersebut ialah terjadilah Perang Kastilla antara Brunei dan Spanyol. Menurut laporan dari Joan Ochoa Ttabudo yang dikutip oleh Haji Umar tertanggal 19 April 1578, bahwa:

"...pada zaman dahulu Raja Brunei telah menghantar mubalighmubaligh Islam (mahoma) ke Cebu, Oton, Manila dan daerah-daerah lain untuk mengembangkan Islam supaya orang di sana sama seperti orang Brunei...di Balayan ugama Islam itu telah diajarkan oleh seorang ulama bernama Sayid Zain..." (Haji Umar, 1990)

Pada zaman pemerintahan Sultan Hasan, sistem pelantikan para pembesar dan pegawai lebih modern. Para ulama yang terdiri dari Datu Imam, Siraja Khatib, Udana Khatib, Khatib dan Mudim pada ketika itu di bawah seliaan Pengiran Temenggong (Sweeney, 1968). Baginda juga terkenal dengan gagah, berani dan adil sehingga Baginda dikasihi oleh rakyatnya (Sweeney, 1968). Dalam pandangan al Mawardi (2002) pemerintah atau imam yang diisyarahkan dalam hadis Nabi adalah dari kabilah Qurasy, karena kabilah ini mempunyai jiwa pemberani, tangguh dan bijaksana, sehingga mempunyai power dan charisma dalam mengatur masyarakat dan empati. Dengan demikian, ketika zaman Sultan Jalilul Jabbar, baginda mentitahkan anakandanya bahwa;

"Apa-apa hal negeri muafakat dengan wazir, cheteria, manteri semuanya serta sekalian sanak saudara, dan apa-apa hukumnya negeri ialah keempat wazir serta cheteria, memberi kapit anakda serta adat istiadatnya mengikut undang-undang kanun, resam dan syara”.(Awang Othman, 2002) 
Setelah beberapa lama, sekitar tahun 1735 semasa pemerintahan Sultan Alauddin, Baginda telah menitahkan Pehin Datu Imam Yaakub untuk menuliskan Silsilah Raja-Raja Brunei. Silsilah ini di sambung dan diselesaikan oleh Pehin Khatib Haji Abdul Latif pada tahun 1807. Kemudian di salin semula oleh Pehin Datu Imam Aminuddin bin Orang Kaya di Gadong Liwaddin pada tahun 1841 (Haji Awang Yahya bin Haji Ibrahim, 2000, hal. 65).

Sekitar tahun 1880 semasa pemerintahan Sultan Abdul Momin, W.H Treacher melaporkan bahwa beberapa orang pencuri telah naik ke kapalnya dan mencuri sebuah jam tangan emas dan selaras senapan. Beliau telah melaporkan hal ini ke hadapan Majelis Duli Yang Maha Mulia Sultan Brunei. Treacher kemudian bergegas ke Pelabuhan ketika penyiasatan dijalankan. Sewaktu beliau di Pelabuhan, barang-barang curian telah dikembalikan kepadanya bersama sepucuk surat dari Sultan yang menyatakan bahwa tiga orang pencuri telah dijatuhkan hukuman potong tangan (Haji Awang Yahya bin Haji Ibrahim, 2000). Peristiwa yang menimpa Sultan Abdul Momin merupakan salah satu contoh kearifan dan kebijaksanaan umara memutuskan hukum bagi pencuri yaitu dengan memotong tangan, salah satu bukti penegakan hukum syariat di hadapan masyarakat Brunei Darussalam pada masa awal.

\section{Era Residen}

Pada tahun 1888 Brunei Darussalam mempunyai perjanjian penting yang tertulis di atas materi, yaitu Perjanjian Perlindungan. Begitu juga Perjanjian 1905/1906 antara Brunei dan pihak British, dan setelah itu Brunei menjadi sebuah negeri yang berada di bawah perlindungan Kerajaan British. Adapun yang disebutkan dalam perjanjian tersebut adalah;

“...Residen akan menjadi ejen dan wakil Kerajaan bagi Great Britain dibawah Pesuruhjaya Tinggi bagi tanah naungan British di Borneo dan nasihatnya mesti di ikut dan di ambil tindakan mengenai semua perkara di Brunei, kecuali perkara-perkara yang menyentuh agama Islam...” (Mohamed, 2011, hal. 236)

Peristiwa ini merupakan sejarah penting dalam perjalanan Brunei sebagai negara bagian dan juga kehidupan masyarakatnya, kecuali dalam sistem agama yaitu Islam yang tidak dapat diikut campuri. Hal ini disebabkan, karena urusan agama akan di bawah koordinasi langsung ulama dan umara. Dalam satu negara yang mempunyai hak priogratif dalam urusan agama, Negara Brunei mengambil keputusan bahwa umara dan ulama telah 
mengambil langkah untuk menubuhkan Majelis Mesyawarah Negeri Brunei pada tahun 1907 dan memberi makluman kepada Pemangku Residen British bahwa 'Tuan Imam adalah seorang pegawai dalam Majelis tersebut mempunyai hak dari segi perlembagaan (Constitutional Right). Pendirian otoritas agama di Brunei Darussalam pada tahun 1907 hingga 1939. Pada masa tersebut, ada tiga tokoh ulama yang pernah dilantik dengan hingar-bingar sebagai majelis agama yang mempunyai otoritas mengatur, berfatwa dan mengeluarkan tafsir agama yaitu; Pehin Tuan Imam Haji Mahyuddin bin Nakhoda Jambul, Pehin Khatib Abdul Razak dan Pehin Datu Imam Haji Abdul Mokti bin Haji Nasar (Haji Awang Yahya bin Haji Ibrahim, 2000). Lebih lanjut, peristiwa penting yang terkait terbentuknya otoritas agama di Brunei terjadi pada tahun 1908 pada zaman Sultan Muhammad Jamalul Alam II yang diinisiasiumara dan ulama, Mahkamah Kadi telah ditubuhkan (Awang Othman, 2002).

Usaha pemerintah Brunei dalam membentuk otoritas agama telah berhasil, dan keberhasilan menjadi sempurna dengan terbentuknya Enakmen Undang-Undang Islam yang dikenali sebagai Mohammedan Law telah diluluskan pada tahun 1911 (Awang Othman, 2002). Secara histori, Imam Haji Mohiddin adalah orang yang mempunyai peran aktif dalam terbentuknya undang-undanga tersebut, karena dia telah mempertanggungjawabkan segala aspek yang berkaitan dengan terbentuknya undang-undang, sehingga kita bisa menyebut sebagai orang yang berjasa atas terbitnya undang-undang keagamaan secara mandiri di negera Brunei (Annual Report on the State of Brunei, 1912, hal. 8). Lebih lanjut, undang-undang agama ini, menembukan bentuk sempurna ketika pada tahun 1913, sebuah enakmen yang berkaitan dengan nikah dan cerai bagi orang-orang Islam telah pun diluluskan dan mendapatkan respon positif untuk diterapkan (Annual Report on the State of Brunei, 1914, hal. 8). Meskipun harus disadari bahwa, materi undang-undang yang tekandung dalam Mohammedan Law belum terlalu komprehensif seperti sekarang, yaitu mengenai nikah dan cerai, sumbang mahram, kehadiran untuk solat Jumaat bagi lelaki, memohon kebenaran untuk mengajarkan ilmu agama, yang mana permohonan tersebut hendaklah dihadapkan kepada Sultan bagi mengelakkan penyebaran doktrin yang salah/sesat kepada masyarakat. Denda yang berbentuk uang akan dimasukkan ke dalam satu tabung khas yang dinamakan 'The Mohammedan Religious Fund' (Muhammedan Law, 1912, pp. 98-101) 
Semakin menguatnya agama dalam kehidupan kenegaraan di Brunei diabadikan dalam bentuk Shaer Yang Di-Pertuan (Hasanuddin, 1979, hal. 725) bahwa secara bersamaan 11 orang ulama telah berkhidmat pada zaman Sultan Jamalul Alam II. Ulama tersebut adalah: pertama, Pehin Datu Imam Haji Abdul Mokti bin Haji Nasar; kedua, Pehin Siraja Khatib Abdul Razak bin Hassanudin; ketiga, Pehin Udana Khatib Haji Mat Daud; keempat, Khatib Abdul Jalil; kelima, Khatib Abdullah; keenam, Khatib Makmun; ketujuh, Khatib Abdul Rahman; kedelapan, Mudim Mohammad; kesembilan, Mudim Jamaluddin; kesepuluh, Mudim Haji Ahmad; kesebelas, Mudim Haji Mohammad Jaafar. Dalam Shaer Yang Di-Pertuan ini juga menggambarkan keadaan Brunei pada zaman Sultan Muhammad Jamalul Alam II dan ini termasuk juga menggambarkan kedekatan 'para ulama dan umara dalam menguruskan kondisi dan visi misi Negeri Brunei terutama sekali dalam hal keagamaan. Keadaan tersebut menandakan bahwa umara yang dipimpin Sultan Jamlul Alam II mempunyai relasi kuat dengan para otoritas keagamaan dalam merumuskan masa depan Negera Brunei yang akan datang, seperti yang ada dalam shaer berikut:

'Haji Abdul Mokti nama diberi

Jadi Dato Imam di dalam negeri

Alimnya sedang bijak dan pari

Layak ikutan masjid berdiri' (Hasanuddin, 1979)

Hubungan umara dan ulama tidak cukup pada masa Sultan Jamalul Alam II, tetapi terus berlanjut ketika pada masa Sultan Ahmad Tajuddin dan Sultan Haji Omar Ali Saifuddien III, sifat mulia yang dimiliki keduanya dalam membangun relasi dengan para ulama ini juga terlihat. Pada zaman Sultan Ahmad Tajuddin, selain mempunyai guru agama secara khusus, baginda kerap bersama ulama dalam masa-masa tertentu seperti berangkat keluar negeri dan menghadiri majlis-majlis keagamaan (Mohamed, 2011). Sebagai seorang Raja yang mementing pendidikan agama, Baginda juga mengarahkan para imam dan khatib untuk mengajar mata pelajaran agama di sekolahsekolah melayu kerajaan pada tahun 1936. Pada tahun 1948, seorang pehin agama dilantik menjadi nazir bagi membentuk kawalan terhadap pelajaran agama di sekolah-sekolah melayu (Haji Awang Yahya bin Haji Ibrahim, 2000).

Baginda juga sempat membangun sekolah arab pertama di Brunei, namun sekolah tersebut di tutup pada zaman Perang Dunia Kedua. Legasi Sultan Ahmad Tajuddin diteruskan oleh adinda Baginda yaitu Sultan Haji 
Omar Ali Saifuddien III. Terkesan dengan perjuangan Sultan Ahmad Tajuddin yang mengutamakan agama sebagai arus utama, Sultan Haji Omar Ali Saifuddien mengorak langkah dengan mendatangkan dua orang pegawai agama dari negeri Johor pada 1955 bagi mengetahui tahap kepahaman rakyat Brunei mengenai agama Islam. Hasil dari laporan tersebut menunjukkan bahwa pengajaran agama di sekolah- sekolah melayu kurang berkesan disebabkan faktor masa yang terlalu singkat (Haji Awang Yahya bin Haji Ibrahim, 2000). Oleh sebab itu, keadaan tersebut menjadi penghambat bagi masyarat untuk mendapatkan ilmu agama dengan masa yang cepat. Menurut Sodima (2013) yang mengkaji Kitab Ta'alim al-Muta'allim menjelaskan bahwa, salah satu ajaran Imam Zarnuji ialah bagi orang yang ingin menguasai ilmu agam dan paham secara menyeluruh diharuskan untuk belajar dalam waktu yang cukup lama, supaya mendapatkan pemahaman yang utuh.

Setelah mendapatkan guru agama yang baik, dan merasa dibutuhkan suatu lembaga untuk penddidikan agama sehingga pada tahun 1956, rencana dan sistem sekolah agama mengikut sistem sekolah agama Negeri Johor. Pada peringkat awal ini, sebanyak tujuh buah sekolah dibina di empat daerah. Hasil dari pembinaah sekolah-sekolah agama tersebut, pengajaran dan pembelajaran agama lebih bersistematik dan teratur (Haji Awang Yahya bin Haji Ibrahim, 2000). Keberhasilan dalam membina dan membina sekolahan agama di empat daerah tersebut tidak lepas dari peran umara yang peduli atas ketertinggalan masyarat dalam belajar agama, sehingga umara mendatangkan ulama untuk memberikan pembelajaran agama supaya dapat memahami ajaran agama dengan baik.

Setelah terbentuk Perlembagaan Brunei pada 29 September 1959, pada zaman Sultan Haji Omar Ali Saifuddien III, Islam menjadi agama rasmi negara dan Sultan adalah sebagai ketua agama. Dengan adanya Perlembagaan Brunei 1959, pelbagai penambahbaikan telah dilaksanakan. Antaranya, kuasa peguam negara tidak berhak dalam urusan bicara di Mahkamah Kadi, seperti yang telah dilakukan oleh Residen British. Pendidikan agama juga telah diambil berat oleh Baginda. Justeru itu, Baginda menubuhkan sekolahsekolah Arab sekitar tahun 60-an.

\section{Era Perlembagaan}

Pada 29 September 1959, sebuah perlembagaan telah dirubah demi menaiktarafkan negara Brunei menjadi sebuah negara yang aman permai. 
Hasrat baginda ini telah dinukilkan dalam Syair Perlembagaan Brunei karangan Baginda sendiri;

'Perlembagaan Brunei nama ditara

Setelah dicadangkan untuk negara

Untuk kebajikan rakyat sugara

Memperbaiki nasib derita sengsara' (Saifuddien, 1994, hal. 3)

Dengan adanya Perlembagaan Brunei 1959, pelbagai penambahbaikan telah dilaksanakan. Antaranya, Islam menjadi agama rasmi bagi Negara Brunei, manakala Sultan adalah sebagai ketua agama. Sistem ini menyerupai status kerjaan Islam pada masa awal, di mana setiap umara sekaligus menjadi ketua atau mempunyai otoritas utama dalam agama. Sehingga setiap putusan memberikan perhatian pada status diri sebagai raja dan otoritas agama yang mengutamakan kemaslahatan rakyat atau umat. Dengan status demikian, kuasa peguam negara tidak berhak dalam urusan bicara di Mahkamah Kadi, seperti yang telah dilakukan oleh Residen British. Pendidikan agama juga telah diambil berat oleh Baginda. Justeru itu, Baginda menubuhkan sekolahsekolah Arab sekitar tahun 60-an.

Sumbangan umara dan ulama dalam era perlembagaan bukan hanya tertumpu kepada keagamaan saja bahkan menjurus kepada kemajuan yang holistik tanpa membelakangi agama, bahkan ahli-ahli mensyuarat negara (council) juga terdiri dari ulama. Antara ulama yang terlibat langsung dalam membangunkan kemajuan ialah; Al-Marhum Pengiran Di-Gadong Pengiran Haji Mohammad Salleh ibni al-Marhum Pengiran Anak Haji Mohammad dan Begawan Pehin Udana Khatib Dato Seri Paduka Haji Awang Umar bin Rendah (H. M. bin Salim, 1992, hal. 60-67). Realitas ini adalah sejarah panjang peran ulama di Negara Brunei dalam ikut serta menyuarakan dan berkontribusi pada negara.

\section{Era Kemerdekaan}

Pada tahun 1967, Sultan Haji Hassanal Bolkiah menaiki takhta yang menggantikan ayahanda Baginda, Sultan Haji Omar Ali Saifuddien dalam menerajui negara Brunei. Seperti ayahandanya, Baginda juga mendampingi para ulama dan menitikberatkan hal agama di Brunei. Pada 1hb Januari, Brunei telah mencapai kemerdekaan. Baginda menekankan bahwa, idealogi Melayu Islam Beraja akan menjadi amalan hidup masyarakat Brunei. Pelbagai usaha juga telah dibuat bagi menjadikan Brunei kekal menjadi sebuah negara 
maju yang mengamalkan ajaran-ajaran Islam dan diridhai Allah SWT, antara usaha terbesar Baginda dan para ulama Brunei ialah menjadikan Brunei Darussalam sebagai sebuah negara Zikir.

\section{Simpulan}

Etimologi ulama dan umara mempunyai kepelbagaian perkataan mengikut kesesuaian tempat, budaya dan masyarakat. Dari segi hubungan pula, umara dan ulama mempunyai hubungan erat dan sama-sama berganding bahu dalam mentadbir sesebuah negara. Seorang umara yang telah dilantik, haruslah memenuhi kriteria-kriteria tertentu seperti yang telah digarispandukan oleh al-Mawardi. Dalam beberapa hal-hal yang berkait, terutama dalam agama, golongan ulama ini lah yang akan membantu para umara dalam melaksanakan hukum-hukum Islam.

Sejarah telah mencatatkan bagaimana hubungan umara dan ulama semasa pemerintahan Islam di Timur Tengah yang mana mereka bertungkus lumus dalam berdakwah dan membangun madrasah-madrasah sehingga menjadi pusat penyebaran ilmu pada ketika itu. Manakala di Alam Melayu, hubungan para umara dan ulama Brunei yang begitu jelas dan erat sejak zaman tradisi lagi sehingga sekarang. Keduanya saling memainkan peranan mereka sesuai dengan keadaan dan keperluan ketika itu. Hasilnya keterlibatan antara keduanya secara langsung menghasilkan perkembangan yang positif kearah pembangunan yang mantap dari pelbagai sudut. 


\section{Referensi}

Adz-Dzahabi, S. (2010). Kitabul-Kabaair. Beirut: Dar al Fikr.

Anas, A. (2018). Konsep Imamah dalam Perspektif Fyiah Imamiyah. Empirisma, 27(1). https://doi.org/https://doi.org/10.30762/empirisma.v27i1.739

Annual Report on the State of Brunei. (1912). Singapore: The Government Printing Office.

Annual Report on the State of Brunei. (1914). Singapore: The Government Printing Office.

Awang Othman, M. S. (2002). Ciri-Ciri Pentadbiran Islam: Dasar dan Perlaksanaan. Bandar Seri Begawan: Institu Perkhidmatan Awam.

Edianto. (2017). Bani Abbasiyah (Pembentukan, Perkembangan dan Kemajuan). al Hikmah, 19(2). Diambil dari http://journal.uinalauddin.ac.id/index.php/al_hikmah/article/view/4136

Haji Awang Yahya bin Haji Ibrahim. (2000). Sejarah dan Peranan Institusi-Institusi Melayu Islam Beraja. Bandar Seri Begawan: Pusat Dakwah Islamiah.

Haji Umar, H. A. M. J. (1990). Tarsilah Brunei I. Bandar Seri Begawan: Pusat Sejarah Brunei.

Hasanuddin, P. S. K. A. R. bin. (1979). Shaer Yang Di-Pertuan. Bandar Seri Begawan: Muzium Brunei.

Hayani, S., \& Bakhtiar, N. (2020). Arabisasi Pemerintahan Islam pada Masa Khalifah Abdul Malik bin Marwan. Jurnal Sejarah Peradaban Islam, 3(2).

https://doi.org/http://dx.doi.org/10.30829/juspi.v3i2.6509

Khaldun, I. (2002). Mukaddimah. Kuala Lumpur: Dewan Bahasa dan Pustaka.

Khallaf, A. W. (1990). Ilmu Ushul al-Fiqh. Mesir: Maktabah al Dakwah al Islamiyah.

Maraghi, M. al-. (2002). Tafsir al-Maraghi. Beirut: Darul Fikir.

Mawardi, A. (2002). al Ahkam al Sulthaniyah. Beirut: Dar al Fikr.

Mohamad Kamil Ab. Majid. (1999). 'Ulama Dan Perubahan Sosial Dalam Islam. Jurnal Usuluddin, 10(10), 81-112.

Mohamed, H. M. H. (2011). Pemerintahan Sultan Ahmad Tajuddin, 1924 - 1950: Kerajaan, Masyarakat dan Perubahan. Bandar Seri Begawan: Pusat Sejarah Brunei.

Muhammedan Law. (1912).

Muslim, K. L. (2019). Umar bin Abdul Azis: Zaman Keemasan Islam masa Dinasti Umayyah. Islam Transformatif, 3(1). Diambil dari http://ejournal.iainbukittinggi.ac.id/index.php/islamt/article/view/797

Qardawi, M. Y. (1997). Bagaimana Memahami Hadis Nabi. Bandung: Karisma.

Qudsy, S. Z. (2013). Umar Bin Abdul Aziz dan Semangat Penulisan Hadis. Esensia, 4(2). https://doi.org/https://doi.org/10.14421/esensia.v14i2.760 
Saifuddien, M. O. 'Ali. (1994). Syair Perlembagaan Negeri Brunei. Bandar Seri Begawan: Dewan Bahasa dan Pustaka.

Salim, H. M. bin (Ed.). (1992). Tokoh-Tokoh Agama Di Brunei: Pengenalan Ringkas. Bandar Seri Begawan: Jabatan Muzium Brunei.

Salim, L. (2015). Peranan Bahasa Arab Terhadap Ilmu Pengetahuan. Jurnal Adabiyah, 15(2).

Sodiman. (2013). Etos Belajar dalam KitabTa'lim Al-Muta'allim Thaariq Al-Ta'allum Karya Imam Al-Zarnuji. Jurnal Al-Ta'dib, 6(2).

Sweeney, P. L. . (1968). Silsilah Raja-Raja Berunai. Journal of the Malaysian Branch of the Royal Asiatic Society, XLI.

Toqus, M. S. (2010). Tarikh al-Daulah al-Umayyah. Beirut: Dar al-Nafais.

Yaacob, P. D. D. A. M. (2017). Institusi Raja di Tanah Melayu. 